\title{
INTAKE, DIGESTIBILITY AND PERFORMANCE OF LAMBS FED WITH DIETS CONTAINING CASSAVA PEELS
}

\author{
Consumo, digestibilidade e desempenho de cordeiros \\ alimentados com dietas contendo casca de mandioca
}

\author{
Gilmara Santos Guimarães ${ }^{1}$, Fabiano Ferreira da Silva ${ }^{2}$, Luciano Lemos da Silva ${ }^{2}$, \\ Luísa Miranda Girardi Galvão ${ }^{3}$, Lenon Machado dos Santos $^{3}$, Alfredo Machado Alencar ${ }^{3}$
}

\begin{abstract}
Sheep farming is designated to economic exploitation, and dry matter intake is the most important factor that influences the performance of animal, thus seeking alternative foods. This study aimed to evaluate the effects of inclusion levels of cassava peel on intake, digestibility and performance of feedlot lambs. We used 32 crossbred lambs Santa Inês uncastrated, mean body weight of 21 $\pm 1.5 \mathrm{~kg}$. Treatments were arranged in a randomized design to animals, with inclusion levels of cassava peel $(0,10,20,30 \%)$ in the diet dry matter and forage cassava leaf hay. During 70 days, there have been weighing the food provided, leftovers, and animals, and feces collection. The intake of dry matter (DMI), organic matter (OMI), crude protein (CPI), ether extract (EEI), neutral detergent fiber corrected for ash and protein (NDIap), total carbohydrates (CTI), non-fiber carbohydrates (NFCI), total digestible nutrients (TDNI), as well as DMI and NDFap/kgCP, DMI and NDFIap/PC ${ }^{0.75}$ levels have not been affected by the inclusion of cassava peel. Similar results for DM digestibility, NDF, CP, MO, CT and the TDN. DEE had a growing linear effect whereas DNFC presented a quadratic effect. Average daily gain (ADG), feed conversion (FC), initial body weight (BWinitial), final body weight (BWfinal), warm carcass weight (WCW) and warm carcass yield (WCR) showed no changes. It is concluded that the peel cassava may be included in diet until $30 \%$, without change dry matter intake and animal performance.
\end{abstract}

Index terms: Average daily gain, nutrition, sheep.

\section{RESUMO}

A criação de ovinos é designada à exploração econômica,e a ingestão de matéria seca é o fator mais importante que influencia o desempenho animal, buscando, assim, alimentos alternativos. Objetivou-se avaliar os efeitos dos níveis de inclusão da casca da mandioca sobre o consumo, digestibilidade e desempenho de cordeiros confinados. Foram utilizados 32 cordeiros mestiços Santa Inês, não castrados, peso corporal médio de $21 \pm 1,5 \mathrm{~kg}$. Os tratamentos foram distribuídos em delineamento inteiramente casualizado aos animais, com níveis de inclusão da casca de mandioca $(0,10,20,30 \%)$ na matéria seca da dieta, e o volumoso o feno da parte aérea de mandioca. Durante 70 dias, realizaram-se pesagens dos alimentos fornecidos, sobras, e animais, e coleta de fezes. O consumo de matéria seca (CMS), matéria orgânica (CMO), proteína bruta (CPB), extrato etéreo (CEE), fibra em detergente neutro corrigida para cinza e proteínas (CFDNcp), carboidratos totais (CCT), carboidratos não fibrosos (CCNF), nutrientes digestíveis totais (CNDT), bem como CMS e FDNcp/kgPC, CMS e CFDNcp/PC ${ }^{0,75}$ não foram alterados pelos níveis de inclusão da casca de mandioca, resultados semelhantes para digestibilidade aparente MS, FDNcp, PB, MO, CT e os valores de NDT. A DEE teve efeito linear crescente e DCNF efeito quadrático. O ganho médio diário (GMD), conversão alimentar (CA), peso corporal inicial (PCi), peso corporal final (PCf), peso de carcaça quente (PCQ) e rendimento de carcaça quente (RCQ) não apresentaram alterações. Conclui-se que a casca da mandioca pode ser incluída na dieta até 30\%, sem comprometer o consumo e desempenho dos animais.

Termos para indexação: Ganho médio diário, nutrição, ovinos.

\section{INTRODUCTION}

Besides contributing to income generation, sheep farming is an economic activity that sustains rural zone families, primarily in the Brazilian semiarid region. Despite this activity increases the consumption of sheep meat in large urban centers it is still poorly explored in certain regions. The sheep breeds raised for meat production grow faster and have a good carcass finishing; however, these are very demanding in terms of food supply and sanitary management. Despite having a carcass appearance that falls short of the expected by consumers, native breeds such as the crossbreed Santa Inês have a remarkable adaptability to the semi-arid conditions prevalent in northeastern Brazil (Araújo Filho et al., 2010).

The sheep meat market has stimulated the production of slaughter lambs, this is important to adapt the production systems. Yet, the intensive sheep industry

1Universidade Estadual do Sudoeste da Bahia/UESB - Campus Juvino Oliveira - BR 415 - KM 04 - Cx. P. 95 - $45.700-000$ - Itapetinga - BA - Brasil gguimaraes114@hotmail.com.

2Universidade Estadual do Sudoeste da Bahia/UESB - Itapetinga - BA - Brasil

${ }^{3}$ Universidade Federal do Recôncavo da Bahia - UFRB - Cruz das Almas - BA - Brasil

Received in july 30, 2013 and approved in february 14, 2014 
encounters obstacles related to feeding costs. Thus, cassava peel industry processing production of cassava flour represents economically viable and cassava peel a co-product with low amounts of protein and lots of fiber and energy, mainly used in feeding animals for fattening. Brazil is a major producer of cassava in the world, with 21milhões tons of planted roots, according to the Brazilian Institute for Geography and Statistics - IBGE (2013), the harvested area in Bahia state was 273/ha. In addition, the main residue of cassava industrialization for flour production is the cassava peel.

A good way to predict the effectiveness of feeding systems is the voluntary consumption of animals. According to Pereira et al. (2008), dry matter intake is the key factor that influences animal performance, since this is the whole point of access to the nutrients especially energy and protein which are necessary to meet the animals requirements. Thus, the physical and chemical characteristics of the food can positively or negatively affect the intake. Moreover, the digestibility coefficients of nutrients also influence the performance, as it allows calculating the apparent quantities absorbed from food in the gastrointestinal tract (Ítavo et al. 2002).This study was aimed at assessing the levels inclusion of cassava peel in the diets of feedlot lambs on intake, nutrient digestibility and animal performance.

\section{MATERIAL AND METHODS}

The experiment was conducted in Rural Family House (RFH)located in Novo Horizonte Farm, in the municipality of President Tancredo Neves, state of Bahia, from February to April 2011.

Thirty two used 32lambs, uncastrated crossbred Santa Inês lambs aged approximately six months, with initial body weight of $21 \pm 1.5 \mathrm{~kg}$ were used. The animals were identified with earrings and wormed. The animals were confined in $12 \mathrm{~m}^{2}$ individual stalls with concrete floor, fitted with drinkers and feeders. The animals were distributed in a completely randomized design with 8 replicates per treatment. The treatments consisted the addition of $0,10,20$, and $30 \%$ cassava peel in dry matter of diet.

Cassava leaf hay was used as forage and the concentrate consisted of corn, soybean, cassava peel and a mineral mixture. The forage:concentrate ratio was 48:52. The diets were formulated so as to meet the nutritional requirements of animals, maintaining and daily gain of $0.2 \mathrm{~kg} / \mathrm{day}$. (Table 1 ).

Cassava leaf hay was granted by COOPATAN (Rural Farmers Cooperative of President Tancredo Neves), which has used the stems and leaves of cassava, making industrial drying. The cassava leaves were chopped in a mill with stationary blades and taken to a dryer whose heat was produced by firewood. Before cassava peel be used directly in the feed, was taken to oven drying. With $15 \%$ $\mathrm{CP}$, the diets were formulated to be isoproteic (Table 2).

The experiment lasted 70 days, seven for adaptation to the facilities and experimental diets, and three periods of 21 days evaluation and collection data. The consumption patterns were adjusted by weighing the provided food and leftovers, considering $10 \%$ the offered amount. The diets were offered twice daily at 08:00 a.m. and 04:00 p.m. as a complete mixture, and water ad libitum.

Samples of the provided foods, leftovers and feces were weighed and placed in plastic bags, and then stored in a freezer at $-5^{\circ} \mathrm{C}$. At the end of the experiment, the collected samples were heated in a forced ventilation oven at 55$65^{\circ} \mathrm{C}$ for 72 hours for determining the pre-dried matter. After that, the samples were ground in a Willey grinder equipped with $1 \mathrm{~mm}$ mesh sieves, and then packaged for laboratory analysis. Dry matter (DM), ether extract (EE),

Table 1 - Chemical composition of the diet ingredients based on dry matter ( $\% \mathrm{DM})$.

\begin{tabular}{ccccc}
\hline Itens & Cassava leaf hay & Corn & Soybean meal & Cassava Peel \\
\hline DM(\%) & 91.28 & 90.16 & 91.97 & 90.64 \\
OM & 92.40 & 98.38 & 93.57 & 98.00 \\
CP & 17.83 & 9.43 & 46.51 & 5.55 \\
EE & 4.77 & 2.22 & 2.34 & 0.67 \\
NDF & 67.32 & 12.53 & 21.39 & 22.65 \\
FDA & 56.62 & 2.13 & 6.27 & 14.36 \\
Hemicellulose & 10.70 & 10.40 & 15.12 & 4.65 \\
Lignin & 15.49 & 1.20 & 1.60 & 7.93 \\
\hline
\end{tabular}

Ciênc. Agrotec., Lavras, v.38, n. 3, p.295-302, maio./jun., 2014 
mineral matter $(\mathrm{MM})$, crude protein $(\mathrm{CP})$, acid detergent fiber (ADF) and lignin contents were determined using the methodologies described by Silva and Queiroz (2002). In turn, the levels of neutral detergent fiber (NDF) were estimated as proposed by Mertens (2002). The corrections to ash and protein contained in NDF were carried out as recommended by Mertens (2002) and Licitra, Hernandez and Van Soest, (1996).

As for the determination of dry matter intake and other components of the diets, the amounts of food offered were daily recorded while leftovers were weekly collected and heavy. Total carbohydrates (TC) have been estimated using the following equation, as proposed by Sniffen et al. (1992):

$\mathrm{TC}=100-(\% \mathrm{CP}+\% \mathrm{EE}+\% \mathrm{MM})$

Non-fiber carbohydrate (NFC) contents were calculated as proposed by Detmann and Valadares Filho (2010):

$\mathrm{NFC}=100-\mathrm{MM}-\mathrm{EE}-\mathrm{NDF}$ ap $-\mathrm{CP}$
Total digestible nutrients (TDN) were determined according to Weiss (1999), using the following equation:

$\mathrm{TDN}=\mathrm{DCP}+\mathrm{DNDFap}+\mathrm{DNFC}+2.25 \mathrm{DEE}$

Where:DCP (digestible CP), DNDFap (digestible NDFap), DNFC (digestible NFC) and DEE (digestible EE).

Between the $30^{\circ}$ and $34^{\circ}$ days of the experimental period, feces samples were collected directly in the rectum ampoule. Sampling followed this distribution: $30^{\circ}$ day, 8:00 a.m. and 02:00 p.m.; $31^{\circ}$ day, 10:00 a.m. and 04:00 p.m.; $32^{\circ}$ day, $12: 00$ and 06:00 p.m.; $33^{\circ}$ day, 02:00 p.m. and 08:00 p.m. and; on the $34^{\circ}$ day, 04:00 p.m. and 10:00 p.m., as proposed by Ferreira et al. (2009). The samples were stored in a freezer $\left(-5^{\circ} \mathrm{C}\right)$. After the end of the experimental period, the stools were dried in an oven with forced ventilation $\left(60{ }^{\circ} \mathrm{C}-72 \mathrm{~h}\right)$ and processed in a Willey Mill equipped with $1 \mathrm{~mm}$ stationary blades and then proportionally composed based on the dry air weight per animal/period, and stored for later analysis. Neutral

Table 2 - Percentage composition of the diet ingredients in dry matter.

\begin{tabular}{|c|c|c|c|c|}
\hline \multirow[b]{2}{*}{ Itens } & \multicolumn{4}{|c|}{ Cassava peel levels (\%) } \\
\hline & 0 & 10 & 20 & 30 \\
\hline Cassava leaf hay & 48.34 & 48.34 & 48.34 & 48.34 \\
\hline Corn & 47.79 & 36.49 & 25.10 & 14.00 \\
\hline Soybean meal & 3.14 & 4.44 & 5.77 & 6.83 \\
\hline Cassava Peel & 0.00 & 10.00 & 20.00 & 30.00 \\
\hline Mineral Salt & 0.48 & 0.48 & 0.48 & 0.48 \\
\hline Dicalcium phosphate & 0.18 & 0.24 & 0.30 & 0.34 \\
\hline \multicolumn{5}{|l|}{ Chemical composition } \\
\hline $\mathrm{DM}(\%)$ & 90.30 & 90.84 & 91.84 & 90.74 \\
\hline $\mathrm{OM}(\mathrm{DM})$ & 94.92 & 94.47 & 94.51 & 94.28 \\
\hline $\mathrm{CP}(\mathrm{DM})$ & 15.49 & 15.29 & 15.44 & 15.75 \\
\hline EE & 3.17 & 3.02 & 2.81 & 2.71 \\
\hline $\mathrm{NDF}$ & 42.94 & 43.11 & 43.46 & 47.62 \\
\hline $\mathrm{ADF}$ & 24.79 & 24.63 & 25.42 & 28.11 \\
\hline NDFap & 38.19 & 39.38 & 41.17 & 40.36 \\
\hline Lignin & 7.94 & 9.34 & 9.62 & 10.97 \\
\hline NFC & 38.68 & 36.96 & 34.78 & 35.51 \\
\hline $\mathrm{TC}$ & 76.87 & 76.35 & 75.95 & 75.86 \\
\hline
\end{tabular}

Assurance levels (nutrient/kg): Calcium-150g; sulfur-12g; phosphorus-65g; magnesium-6.000mg; sodium-107g; copper-100mg; cobalt-175mg; iron-1000mg; maximum fluor-650mg; iodine-175mg ; manganese-1440mg; selenium-27mg and zinc-6000mg. 
detergent fiber indigestible (iNDF) has been used as an internal indicator for estimating thedaily fecal excretion in the samples provided, leftovers and feces. To this end, an in situ digestibility procedure has been adopted, for $288 \mathrm{~h}$, as suggested by Valente et al (2011).

The lambs were weighted at the beginning of the experiment and every 21 days for weight control. At the end of the experimental period, weighing was conducted so as to verify the average daily gain. The lambs have gone through a fasting period of 16 hours and then weighed to verify the fasting body weight (FBW). Next, the animals were slaughtered to obtain the warm carcass weight (WCW) and calculate the warm carcass yield (WCY) through the formula (WCY $\left.=\mathrm{WCW} / \mathrm{WCA}^{*} 100\right)$.

The statistical analyzes of data were carried out using the Statistical and Genetics Analysis System (SAEG) through analysis of variance and regression at a significance level of $5 \%$.

\section{RESULTS AND DISCUSSION}

The intake of DM and nutrients were not affected $(\mathrm{P}>0.05)$ by cassava peel inclusion, as shown in table 3 .

The average dry matter intake was $0.848 \mathrm{~kg} /$ day. The fiber contents in the experimental diets were increasing (Table 2), but did not affect the intake parameters of DM and OM, which are deemed important in animal performance. According to Mertens (1994), diets with high levels of energy consumption is determined by meeting the nutritional requirements of the animal and diets with low energy levels the limiting factor is the physical capacity for intake. Yet, it is positively correlated when energy is the limiting factor. The great potential of NDF degradation from cassava peel was probably the key determinant that prevented the fiber source from causing physical limitations to DMI.

A minor intake was obtained by Faria et. at. (2011), in a work involving different methods of processing cassava peel, where the average dry matter intake ranged from 426.71 to $478.08 \mathrm{~g} /$ day. In a study involving cassava in the diets of feedlot sheep, Conceição et. al. (2009) have noted that the voluntary intake of dry matter and organic matter were not affected $(\mathrm{P}>0.05)$ by the inclusion of up to $48 \%$ in the diet.

The crude protein intakes (CPI) expressed as $\mathrm{kg}$ /day from animals fed different peel cassava levels have shown an average value of $0.132 \mathrm{~kg} /$ day. The noneffect for DMI has affected the results in CPI, which bear direct relationship. Furthermore, the diets were isoproteic and have not therefore contributed to the variation of results. Lower CPI values were verified by Menezes et. al. (2004), who worked in the replacement of corn by cassava peel in complete mixed feeds for goats, verified crude protein intakes of $127.13 ; 120.14$; and $118.30 \mathrm{~g} /$ day for cassava peel levels of $0.33 \%$ and $66 \%$.

The EEC averaged $0.024 \mathrm{~kg} /$ day, with no influence of cassava peel, as the contents of EE the experimental diets were close, not influencing the EEC.

There was no effect $(\mathrm{P}>0.05)$ for intake NDFap because this result followed the behavior of the DM. In the knowledge that the energy of food comes from organic compounds such as $\mathrm{CP}, \mathrm{EE}, \mathrm{NFC}$ and also fibrous fractions, there was no effect regarding the intake of TDN; thus, the similar levels of such variables in the diets may have contributed to this result.

The results showed that there was no difference ( $\mathrm{P}>0.05$ ) among the diets for DDM, DNDFap, DCP, DOM, DTC and TDN values, presented in table 4.

With a mean value of $67.36 \%$, DDM was not influenced by the inclusion of cassava peel. In the evaluation of corn replacement by cassava in the diet of goats, Menezes et al (2004) have observed that the digestibility coefficient of DM ranged from 70.32 to $59.01 \%$. In a study assessing the in situ rumen degradability. On the other hand, DEE showed a growing linear effect with the inclusion of cassava peel. Such behavior may be the result of a higher digestion rate ofEE from cassava peel as compared to other foods present in experimental diets (Table 2).

A quadratic effect was observed for DNFC, with a maximum value of 94.90 for the level of $21.33 \%$ cassava peel. This can be explained by the fact thatstarch cassava peelis of better digestibility than that of corn. According to Zeoula et al. (1999) the rumen degradability of cassava starch is higher(79.1\%) as compared to that of corn (57.8\%).

TDN content has not varied amongthe diets ( $P>0.05$ ), with a mean value of $64.43 \%$ (Table 4 ), which is close to meet the nutritional requirements of sheep (66.01\%), according to the National Research CouncilNRC (2007).

With respect to the performance parameters, it has been found that ADG, FC, FE, BW initial, BW final and WCY were not significantly affected $(\mathrm{P}>0.05)$ by the inclusion of cassava peel.

A mean value of $0.152 \mathrm{~kg} /$ day has been verified for ADG. Corroborating this work, witha study by Faria et al. (2011), addressing the various processing methods of cassava peel for the diet of sheep has found an average weight gain of $0.150 \mathrm{~kg}$ per day. 
Table 3 - Nutrient intake by lambs fed diets containing different levels of cassava peel.

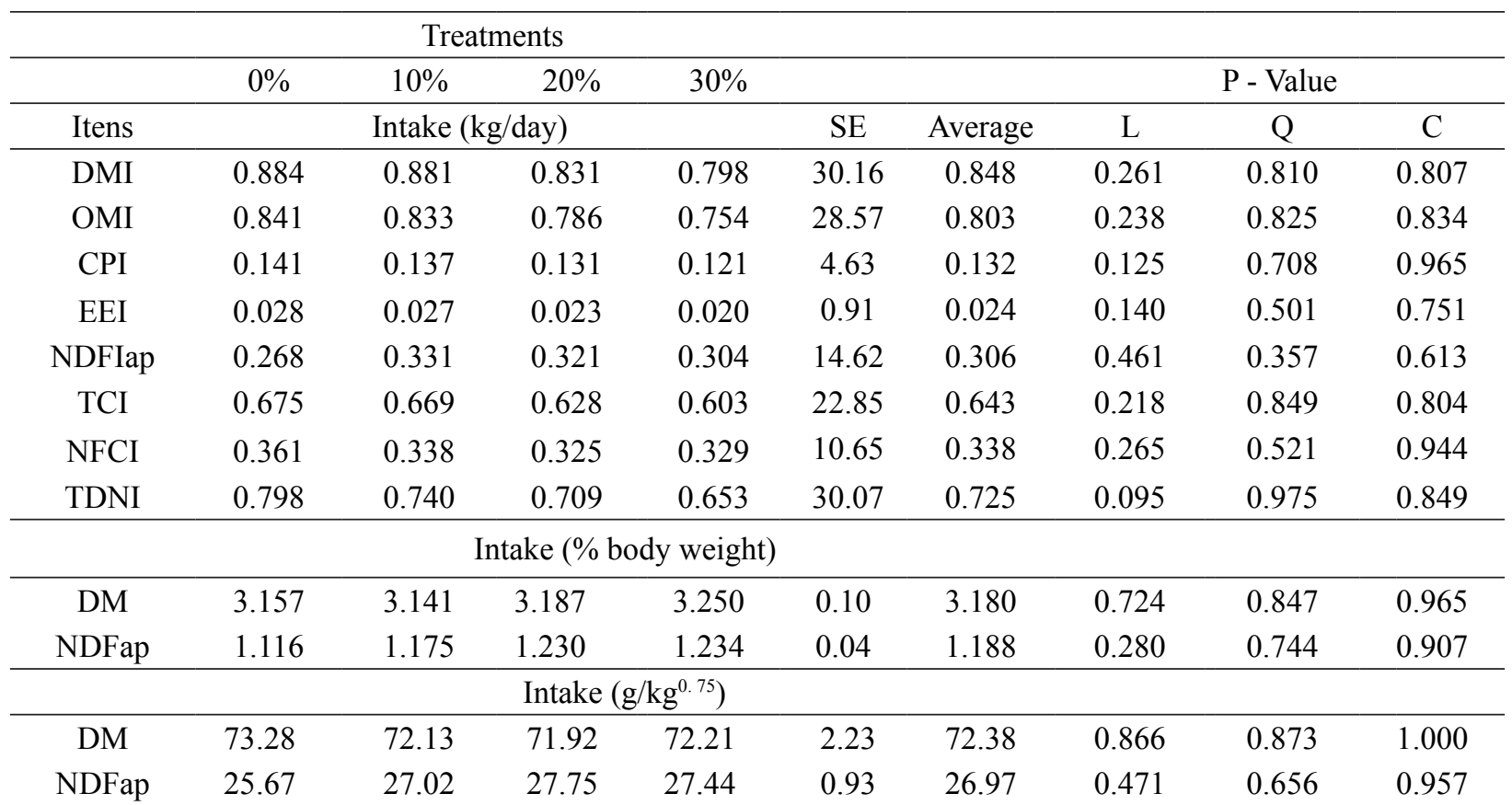

Dry matter intake (DMI), organic matter intake (OMI), crude protein intake (CPI), ether extract intake (EEI), intake of neutral detergent fiber corrected for ash and protein (INDFap), total carbohydrates intake (TCI), non-fiber carbohydrates intake (NFCI) and total digestible nutrients (TDNI). SE (standard error), Linear (L), Quadratic (Q), Cubic (C).

Table 4 - Apparent digestibility of nutrients and total digestible nutrients in lambs fed containing different levels of cassava peel.

\begin{tabular}{cccccccccc}
\hline \multicolumn{9}{c}{ Diets } \\
\hline Items & $0 \%$ & $10 \%$ & $20 \%$ & $30 \%$ & SE & Average & L & Q & C \\
\hline DDM & 66.28 & 66.46 & 70.53 & 66.19 & 0.786 & 67.36 & 0.593 & 0.161 & 0.091 \\
DNDFap & 48.37 & 43.65 & 52.92 & 41.86 & 1.445 & 46.70 & 0.433 & 0.281 & 0.013 \\
DCP & 52.54 & 53.96 & 58.57 & 59.56 & 1.282 & 56.15 & 0.076 & 0.944 & 0.628 \\
DEE & 61.21 & 61.14 & 61.24 & 69.24 & 1.247 & 63.20 & ${ }^{1} 0.019$ & 0.080 & 1.000 \\
DOM & 66.77 & 67.05 & 71.09 & 67.03 & 0.790 & 67.98 & 0.502 & 0.180 & 0.104 \\
DTC & 69.28 & 69.48 & 73.51 & 68.05 & 0.783 & 70.08 & 0.965 & 0.081 & 0.067 \\
DNFC & 87.98 & 94.09 & 94.95 & 94.52 & 0.720 & 92.88 & 0.004 & ${ }^{2} 0.033$ & 0.550 \\
TDN & 62.97 & 63.20 & 66.86 & 64.72 & 0.791 & 64.43 & 0.216 & 0.461 & 0.550
\end{tabular}

Apparent dry matter digestibility (DMD), neutral detergent fiber corrected for ash and protein (DNDFap), crude protein (DCP), ether extract (DEE), organic matter (DOM), total carbohydrates (DTC), non-fiber carbohydrates (DNFC) and total digestible nutrients (TDN); L (linear); Q (quadratic); C (cubic); SE (standard error); ${ }^{1} \hat{\mathrm{Y}}=0.2418 \mathrm{x}+59.581\left(\mathrm{r}^{2}=0.6025\right) ;{ }^{2} \hat{\mathrm{Y}}=-0.0163 \mathrm{x} 2+0.6952 \mathrm{x}+$ $88.175\left(r^{2}=0.9759\right)$

Feed conversion is defined as the DMI:ADG ratio, representing the efficiency with which the animal converts food in to protein of animal origin. Hence, once DMI and ADG were not affected by cassava peel, these have contributed to the results of feed conversion, which were not affected $(\mathrm{P}>0.05)$ by the inclusion the same(Table 5$)$. 
Table 5 - Performance of lambs fed diets containing different levels of cassava peel.

\begin{tabular}{cccccccccc}
\hline \multicolumn{9}{c}{ Diets } \\
\hline Itens & $0 \%$ & $10 \%$ & $20 \%$ & $30 \%$ & SE & Average & L & Q & C \\
\hline ADG $(\mathrm{kg})$ & 0.149 & 0.154 & 0.153 & 0.153 & 0.040 & 0.152 & 0.907 & 0.903 & 0.939 \\
FC (kg) & 6.690 & 6.150 & 5.860 & 5.480 & 0.072 & 6.040 & 0.293 & 0.921 & 0.925 \\
FE (kg) & 0.167 & 0.170 & 0.179 & 0.190 & 0.052 & 0.176 & 0.355 & 0.823 & 0.944 \\
BWi (kg) & 21.95 & 23.20 & 21.50 & 20.38 & 0.845 & 21.75 & 0.406 & 0.492 & 0.647 \\
BWf (kg) & 31.33 & 32.89 & 30.75 & 30.00 & 1.732 & 31.24 & 0.421 & 0.496 & 0.502 \\
WCW (kg) & 15.17 & 15.17 & 13.81 & 13.30 & 0.391 & 14.36 & 0.056 & 0.744 & 0.531 \\
WCY (\%) & 45.53 & 46.05 & 44.13 & 44.41 & 0.358 & 45.03 & 0.110 & 0.866 & 0.160 \\
\hline
\end{tabular}

Average daily gain (ADG), feed conversion (FC), feed efficiency (FE), initial body weight (BWi), final body weight (BWf), warm carcass weight (WCW), warm carcass yield (WCR); SE (standard error); L (linear); Q (quadratic); C (cubic).

The mean value found for WCY was $45.03 \%$ (Table 5).The similarity of body weight, associated with a similar age have possibly prevented that the carcass yield was affected; the reason is that, according to Cezar and Sousa (2007), amongst the factors intrinsic to animals, body weight and age are probable the ones that most influence the carcass yield. According to Macedo, Siqueira and Martins (1999), the carcass yield of sheep may vary from 40 to $50 \%$. Lower carcass yield values $(39.46 \%)$ were reported by Furusho-Garcia et al. (2010) in a study involving Santa Inês sheep slaughtered at an average weight of $38 \mathrm{~kg}$.

\section{CONCLUSION}

The peel of cassava can be included in the diet up to $30 \%$ with no change on intake and animal performance.

\section{REFERENCES}

ARAÚJO FILHO, J.T. et al. Desempenho e composição da carcaça de cordeiros deslanados terminados em confinamento com diferentes dietas. Revista Brasileira de Zootecnia. 39(2):363-371, 2010.

CEZAR, M. F. SOUSA, W. H. Carcaças ovinas e caprinas: obtenção-avaliação-classificação. Editora Agropecuária Tropical, Uberaba, 2007.147p.

CONCEIÇÂO,W. L.F. et al.Valor nutritivo de dietas contendo raspa integral da mandioca para ovinos confinados. Acta Scientiarum.Animal Sciences. 31(4):397-402, 2009.
DETMANN, E.; VALADARES FILHO, S.C. On the estimation of non-fibrous carbohydrates in feeds and diets. Arquivo Brasileiro de Medicina Veterinária e Zootecnia. 62(4):980-984, 2010.

FARIA. B. P. et al. Processamento da casca de mandioca na alimentação de ovinos: desempenho, características de carcaça, morfologia ruminal e eficiência econômica. Revista Brasileira de Zootecnia. 40(12):2929-2937, 2011.

FERREIRA, M.A. et al. Avaliação de indicadores em estudos com ruminantes: digestibilidade. Revista Brasileira de Zootecnia. 38:1568-1573, 2009.

FURUSHO-GARCIA, I. F.; et al .Performance and carcass characteristics of Santa Inês pure lambs and crosses with Dorper e Texel at different management systems. Revista Brasileira de Zootecnia. 39(6):13131321, 2010.

\section{INSTITUTO BRASILEIRO DE GEOGRAFIA E ESTATÍSTICA IGBE. [2031]. Indicadores IBGE - Estatística da Produção Agrícola. Available at: $<$ http://www.ibge.gov.br/home/estatistica/indicadores/ agropecuaria/lspa/lspa_201303comentarios.pdf> Accessed on: March. 2013.}

ÍTAVO, L. C. V. et al. Consumo e digestibilidade aparentes totais e parciais de nutrientes em novilho alimentados com dietas contendo vários níveis de concentrado. Revista Brasileira de Zootecnia. 31(3):1543-1552, 2002. 
LICITRA, G.; HERNANDEZ, T.M.; VAN SOEST, P.J. Standardization of procedures for nitrogen fractionation of ruminat. Feed Science and Technology. 57(4):347358, 1996.

MACEDO, F.A.F.; SIQUEIRA, E.R.; MARTINS, E. N. Desempenho de cordeiros corriedale puros e mestiços, terminados em pastagem e em confinamento. Arquivo Brasileiro de Medicina Veterinária e Zootecnia. 51(6):583-587, 1999.

MENEZES, M.P.C. et al. Substituição do milho pela casca de mandioca (Manihot esculenta Crantz) em rações completas para caprinos: consumo, digestibilidade de nutrientes e ganho de peso. Revista Brasileira de Zootecnia. 33(3):729-737, 2004.

MERTENS, D.R. Regulation of forage intake. In: Fahey Jr., D.C. Forage quality, evaluation and utilization. American Society of Agronomy, Madison. p. 450-492, 1994.

MERTENS, D. R. Gravimetric determination of amylase-treated neutral detergent fiber in feeds with refluxing in beakers or crucibles: collaborative study.

Journal of AOAC International. 85:1217-1240, 2002.

NATIONAL RESEARCH COUNCIL - NRC. Nutrient requirements of sheep. $6 \mathrm{a}$ ed. Washington, D. C.: National Academy Press, 2007. 362p.
PEREIRA, O.G. et al. Consumo e digestibilidade dos nutrientes e desempenho de bovinos de corte recebendo dietas com diferentes níveis de uréia. Ciência Animal Brasileira. 9(3):552-562, 2008.

SILVA, D. J.; QUEIROZ, A. C. Análise de alimentos (métodos químicos e biológicos). 3 ed. Viçosa: Universidade Federal de Viçosa, UFV, 2002. 235p.

SNIFFEN, C. J. et al. A net carbohydrate and protein system for evaluating cattle diets. II. Carbohydrate and protein availability. Journal of Animal Science.70(7):3562-3577, 1992.

VALENTE, T. N. P. et al. Evaluation of ruminal degradation profiles of forages using bags made from different textiles. Revista Brasileira de Zootecnia. 40(11):2565-2573, 2011.

WEISS, W. P. Energy prediction equations for ruminant feeds. In: CORNELL NUTRITION CONFERENCE FOR FEED MANUFACTURES,61, 1999, Ithaca. Proceedings. Ithaca: Cornell University, 1999. p.176185.

ZEUOLA, L. M. et al. Solubilidade e degradabilidade ruminal do amido de diferentes alimentos. Revista Brasileira de Zootecnia. 28(5):905-912, 1999. 
